\title{
TINGKAT PRAVELEANSI KECACINGAN PADA SISWA SEKOLAH DASAR DI BEBERAPA DAERAH INDONESIA
}

\author{
Noeril Asy Syifa Zahara \\ Fakultas Kedoktern, Universitas Lampung, Jl. Prof. DR. Ir. Sumatri Brojonegoro No.1, Gedong Meneng, \\ Kec. Rajabasa, Kota Bandar Lampung, Lampung, Indonesia 35145 \\ Nurilasifa78@gmail.com (+6289620167592)
}

\begin{abstract}
ABSTRAK
Infeksi kecacingan yang disebabkan oleh Soil Transmitted Helminths (STH) telah menjadi masalah umum kesehatan masyarakat Indonesia. Kemunculan infeksi kecacingan berawal dari pola hidup yang tidak bersih. Edukasi pola hidup bersih telah banyak dilakukan untuk mencegah penyakit kecacingan, namun efektivitas edukasi perlu dipelajari lebih lanjut dengan menelaah metode pada penelitian-penelitian sebelumnya. Penelitian ini bertujuan menganalisis tingkat praveleansi kecacingan di beberapa daerah dan mengetahui efektivitas edukasi kecacingan. Penelitian menggunakan metode literature review untuk menganalisis dan menginterpretasikan hasil penelitian-penelitian kejadian kecacingan sebelumnya. Hasil penelitian menunjukkan 255 positif kecacingan dari 859 sampel dengan tingkat praveleansi total sebesar 29,7\%. Kasus tertinggi terdapat pada SDN I Manurung, Kalimantan Selatan dengan tingkat praveleansi sebesar $68,4 \%$. Hasil analisis dari literatur review menunjukkan faktor pola hidup bersih dan sanitasi lingkungan berperan dalam penularan kecacingan. Infeksi ganda oleh dua jenis cacing pada sampel tinja menunjukkan kebersihan diri dan lingkungan yang kurang terjaga. Metode edukasi dan pelayanan informasi terhadap infeksi dan penularan kecacacingan perlu ditingkatkan secara konsisten di daerah tergolong praveleansi tinggi. Bantuan dan dukungan pemerintah setempat akan mendorong keberhasilan penurunan praveleansi kecacingan.
\end{abstract}

Kata kunci: ascaris lumbricoides; edukasi; infeksi kecacingan; literature review; trichuris trichiura

\section{LEVEL OF WORM INFESTATION IN ELEMENTARY SCHOOL STUDENTS IN SEVERAL REGIONS OF INDONESIA}

\begin{abstract}
Worm infections caused by Soil Transmitted Helminths (STH) have become a common public health problem in Indonesia. The emergence of helminth infections begins with an unclean lifestyle. A lot of education on clean lifestyle has been done to prevent helminthiasis, but the effectiveness of education needs to be studied further by examining the methods in previous studies. This study aims to analyze the prevalence of worms in several areas and to determine the effectiveness of worm education. The study used the literature review method to analyze and interpret the results of previous studies of helminthiasis. The results showed 255 positive for helminthiasis from 859 samples with a total prevalence rate of $29.7 \%$. The highest case was at SDN I Manurung, South Kalimantan with a prevalence rate of $68.4 \%$. The results of the analysis of the literature review show that clean lifestyle factors and environmental sanitation play a role in the transmission of worms. Multiple infections by two types of worms in stool samples indicate poor personal and environmental hygiene. Educational methods and information services on helminth infections and transmission need to be consistently improved in areas classified as high prevalence. Help and support from the local government will encourage the success of reducing the prevalence of worms.
\end{abstract}


Keywords: ascaris lumbricoides; education; literature review; trichuris trichiura; worm infection

\section{PENDAHULUAN}

Soil Transmitted Helminthes (nematoda usus yang ditularkan melalui tanah) berkembang baik pada daerah iklim tropis dengan kelembaban yang tinggi, seperti Indonesia. Penyakit kecacingan di Indonesia merupakan masalah kesehatan masyarakat terbanyak setelah malnutrisi (Darmiah et al, 2015). Penyakit yang disebabkan oleh Soil Transmitted Helminths atau dikenal dengan cacing usus merupakan penyakit infeksi paling umum menyerang kelompok masyarakat ekonomi lemah. Penyakit akibat cacing dan infestasi protozoa usus sering dikaitkan dengan faktor sanitasi, pendidikan, sosial ekonomi dan perilaku sehari-hari. Anak usia sekolah dasar (SD) merupakan kelompok umur yang paling sering terinfeksi oleh parasit usus. Sebesar 12 $\%$ dari kesakitan total siswa umur 5 14 tahun di negara berkembang terinfeksi cacing, dan pada umur ini merupakan masa sekolah dan kelompok yang rentan terhadap penularan penyakit.

Cacing-cacing yang menginfestasi anak dengan prevalensi yang tinggi adalah cacing gelang (Ascaris lumbricoides), cacing cambuk (Trichuris trichiura), cacing tambang (necator americanus) dan cacing pita. Cacing-cacing yang tinggal di usus manusia ini memberikan kontribusi yang sangat besar terhadap kejadian penyakit lainnya, seperti kurang gizi oleh infestasi cacing gelang yang mengonsumsi karbohidrat dan protein di usus sebelum diserap oleh tubuh, kemudian, penyakit anemia (kurang kadar darah) oleh cacing tambang yang mengisap darah di usus, cacing cambuk dan cacing pita yang mengganggu pertumbuhan dan perkembangan anak, serta mempengaruhi masalah-masalah non kesehatan lainnya, contoh pada menurunnya prestasi belajar dan drop outnya anak SD (Mardiana et al, 2008).

Infeksi cacing usus merupakan infeksi kronik yang banyak menyerang anak balita dan anak usia sekolah dasar. Faktor-faktor risiko penyebab tingginya prevalensi penyakit cacingan adalah rendahnya tingkat sanitasi pribadi (Perilaku Hidup Bersih Sehat) dan buruknya sanitasi lingkungan (Umar, 2008). Perilaku yang menjadi penyebab infeksi cacingan antara lain, tidak mencuci tangan sebelum makan dan setelah buang air besar (BAB), tidak menjaga kebersihan kuku, perilaku jajan di sembarang tempat, perilaku $\mathrm{BAB}$ tidak di WC sehingga mencemari tanah oleh feses yang terdapat telur cacing, dan kurangnya ketersediaan sumber air bersih (Hanif, 2017).

Adanya program pemberantasan kecacingan pada anak dan penyuluhan sanitasi lingkungan, serta pola hidup bersih kepada masyarakat merupakan salah satu program terdepan untuk meningkatkan derajat kesehatan masyarakat. Tujuan program pemberantasan kecacingan ini adalah penurunan angka kejadian kecacingan, meningkatkan cakupan program pengendalian penyakit kecacingan bersama mitra antara masyarakat, pemerintahan, serta swasta pada siswa sekolah dasar (Isma et al, 2018). Pengkajian lebih lanjut mengenai edukasi pola hidup bersih dan pemberantasan kecacingan di tingkat sekolah dasar menjadi dasar kuat untuk meningkatkan kesehatan masyarakat. Penelitian ini bertujuan mengetahui 
efektivitas edukasi kecacingan untuk mempelajari inovasi baru edukasi pola hidup bersih dan penyakit kecacingan pada siswa sekolah dasar.

\section{METODE}

Metode yang digunakan adalah Systematic Literature Review dengan menelaah, mengidentifikasi, mengkaji, dan menyajikan data. Metode penelitian ini menggabungkan data-data penelitian sebelumnya terkait kejadian infeksi kecacingan. Metode ini melakukan pengkajian kembali materi dan membandingkan hasil yang disajikan oleh artikel untuk mendapatkan hasil dan menyimpulkan tingkat praveleansi dan penyebab utama kecacingan untuk membantu pemberantasan kecacingan pada program kesehatan pemerintah. Metode yang digunakan adalah mencari sumber kejadian kecacingan di Siswa Sekolah Dasar di beberapa daerah di Indonesia. Hal ini karena anak-anak berumur 5-12 tahun paling rentan terkena infeksi kecacingan dan merupakan kelompok umur yang menjadi sasaran dalam program Penanggulangan Cacingan adalah balita, anak usia pra sekolah dan anak usia sekolah berdasarkan Peraturan Menteri Kesehatan Republik Indonesia Nomor 15 Tahun $2017 \quad$ Tentang Penanggulangan Cacingan. Jurnal ilmiah yang digunakan sebanyak tujuh jurnal untuk data primer dan acuan penulisan lainnya digunakan jurnal dalam rentang tahun 2011 - 2020.

\section{Jumlah Kejadian Kecacingan pada Sekolah Dasar dan Tingkat Pravelensinya}

Angka presentase kejadian kecacingan tertinggi berdasarkan studi ini terdapat pada penelitian Hairani dan Juhairiyah (2015) pada pemeriksaan feses Siswa SDN 01 Manurung di Kalimantan Selatan sebanyak $68,4 \%$ dari total 98 siswa. Berbeda dengan Siswa SDN 4 Sulangai, Kabupaten Badung, Bali yang tidak terdapat kejadian kecacingan pada 87 sampel feses yang diperiksa atau 0\% kejadian kecacingan (Krishnandita et al. 2019). Hal ini membuktikan bahwa kejadian kecacingan dapat dicegah hingga $0 \%$ pada usia dini dalam upaya meningkatkan kesehatan masyarakat.

Perbandingan yang terjadi pada kedua kasus tersebut setelah dianalisis lebih jauh terdapat pada tingkat pengetahuan dan kesadaran menjaga pola hidup bersih. Penelitian oleh Isma et al. (2018) terhadap pemeriksaan feses Siswa di empat Sekolah Dasar di Puskesmas Rowosari Kecamatan Tembalang Semarang juga menunjukkan hasil negatif $0 \%$ dari 96 orang. Hasil penelitian tersebut menyebutkan presentase pengetahuan terhadap tanda kecacingan, cara penularan, dan pencegahan infeksi kecacingan menjadi salah satu penilaian pada kejadian kecacingan hingga $0 \%$. Presentase kejadian kecacingan pada siswa beberapa sekolah dasar di Indonesia diperoleh pada Tabel 1.

\section{HASIL}

Tabel 1, total kumulatif presentase positif terhadap 859 data yang menunjukkan positif kecacingan sebanyak 29,7\% atau 255 siswa sekolah dasar mengalami kecacingan. Peraturan Menteri Kesehatan Republik Indonesia Nomor 15 Tahun 2017 Tentang Penanggulangan Cacingan menyebutkan bahwa Tingkat prevalensi untuk kabupaten/kota dalam kategori tinggi apabila prevalensi Cacingan di atas $50 \%$ (lima puluh persen); prevalensi sedang apabila prevalensi Cacingan 20\% (dua puluh persen) sampai dengan 50\% (lima puluh persen); dan prevalensi rendah apabila prevalensi Cacingan dibawah 20\% (dua 
puluh persen). Data pravelensi cacingan pada delapan Sekolah Dasar yang menunjukkan semua tingkatan dianalisis berdasarkan kabupaten/kota pravelensi (Tabel 2).

Tabel 1.

Angka kejadian kecacingan pada beberapa Sekolah Dasar di Indonesia

\begin{tabular}{llcccc}
\hline No & \multicolumn{1}{c}{ Lokasi sekolah } & $\begin{array}{c}\text { Jumlah } \\
\text { Siswa (n) }\end{array}$ & Positif & $\begin{array}{c}\text { Presentase } \\
\text { kejadian } \\
\text { kecacingan (\%) }\end{array}$ & Sumber \\
\hline 1 & $\begin{array}{l}\text { SDN X Pagi Paseban, Jakarta } \\
\text { Pusat }\end{array}$ & 113 & 13 & $11,5 \%$ & $\begin{array}{l}\text { Winita } \text { et al. } \\
2012\end{array}$ \\
\hline 2 & SDN 2 Malaka, Lombok Utara & 18 & 10 & $55,5 \%$ & $\begin{array}{l}\text { Sari } \text { et al. } \\
2019\end{array}$ \\
\hline 3 & $\begin{array}{l}\text { SDN 47 Ampean, Lombok } \\
\text { Timur }\end{array}$ & 68 & 21 & $30,8 \%$ & $\begin{array}{l}\text { Triana } \text { et al. } \\
\text { 2020 }\end{array}$ \\
\hline 4 & $\begin{array}{l}\text { SDN Inpres No.1 Wora } \\
\text { Kecamatan Wera Kabupaten } \\
\text { Bima }\end{array}$ & 91 & 54 & $59,3 \%$ & $\begin{array}{l}\text { Syahrir dan } \\
\text { Aswadi 2016 }\end{array}$ \\
\hline 5 & $\begin{array}{l}\text { SDN 4 Sulangai, Kabupaten } \\
\text { Badung, Bali }\end{array}$ & 87 & 0 & $0 \%$ & $\begin{array}{l}\text { Krishnandita } \\
\text { et al. 2019 }\end{array}$ \\
\hline 6 & $\begin{array}{l}\text { SDN I Manurung, Kalimantan } \\
\text { Selatan }\end{array}$ & 98 & 67 & $68,4 \%$ & $\begin{array}{l}\text { Hairani dan } \\
\text { Juhairiyah } \\
\text { 2015 }\end{array}$ \\
\hline 7 & $\begin{array}{l}\text { SD di Kelurahan Watusampu } \\
\text { dan kelurahan Lolu Utara, } \\
\text { Sulawesi Tengah }\end{array}$ & 288 & 90 & $31,3 \%$ & $\begin{array}{l}\text { Chadijah } \text { et } \\
\text { al. 2014 }\end{array}$ \\
\hline 8 & $\begin{array}{l}\text { Sekolah Dasar di Puskesmas } \\
\text { Rowosari Kecamatan } \\
\text { Tembalang Semarang }\end{array}$ & 96 & 0 & $0 \%$ & $\begin{array}{l}\text { Isma } \text { et al. } \\
\text { 2018 }\end{array}$ \\
\hline Keterangan: (n) Jumlah siswa yan & & & & & \\
\hline
\end{tabular}

Keterangan: $(\mathrm{n})=$ Jumlah siswa yang bersedia diperiksa feses

Tabel 2.

Tingkat prevalensi cacingan pada beberapa Sekolah Dasar di Indonesia

\begin{tabular}{ccl}
\hline Tingkat pravelensi & Kategori & \multicolumn{1}{c}{ Sekolah Dasar } \\
\hline$>50 \%$ & Tinggi & $\begin{array}{l}\text { SDN 2 Malaka, Lombok Utara; SDN Inpres No.1 } \\
\text { Wora Kecamatan Wera Kabupaten Bima; SDN I } \\
\text { Manurung, Kalimantan Selatan }\end{array}$ \\
\hline $20 \%-50 \%$ & Sedang & SDN 47 Ampean, Lombok Timur; SD di \\
& & Kelurahan Watusampu dan kelurahan Lolu Utara, \\
& Sulawesi Tengah \\
\hline$<20 \%$ & Rendah & SDN X Pagi Paseban, Jakarta Pusat; SDN 4 \\
& Sulangai, Kabupaten Badung, Bali; Sekolah Dasar \\
& di Puskesmas Rowosari Kecamatan Tembalang \\
& Semarang \\
\hline
\end{tabular}

Keterangan: Kategori dan tingkat pravelensi berdasarkan peraturan Kesehatan Republik Indonesia Nomor 15 Tahun 2017 


\section{Jenis-Jenis Cacing pada Infeksi Kecacingan}

Jenis cacing yang ditemukan berdasarkan data Hairani dan Juhairiyah (2015) sebesar 22,4\% adalah Trichuris trichiura atau yang dikenal dengan cacing cambuk, sementara itu, penelitian lain yang ditemukan oleh Indriyanti et al. (2017) juga menunjukkan presentase tinggi ditemukannya $T$. trichiura sebesar $35,8 \%$. Hasil analisis pada siswa di delapan sekolah dasar dalam studi ini juga menunjukkan dominan jenis cacing yang menginfeksi adalah Trichuris trichiura, Ascaris lumbricoides, dan campuran $T$. trichiura dan $A$. lumbricoides (Tabel 3).

Tabel 3.

Jenis cacing yang ditemukan dalam pemeriksaan feses

\begin{tabular}{|c|c|c|c|}
\hline No & Lokasi sekolah & Jenis cacing & Sumber \\
\hline 1 & $\begin{array}{l}\text { SDN X Pagi Paseban, } \\
\text { Jakarta Pusat }\end{array}$ & $\begin{array}{l}\text { Ascaris lumbricoides, Trichuris } \\
\text { trichiura }\end{array}$ & $\begin{array}{l}\text { Winita et al. } \\
2012\end{array}$ \\
\hline 2 & $\begin{array}{l}\text { SDN } 2 \text { Malaka, Lombok } \\
\text { Utara }\end{array}$ & $\begin{array}{l}\text { Trichuris trichiura, infeksi } \\
\text { campuran } T . \text { trichiura dan } A . \\
\text { lumbricoides }\end{array}$ & Sari et al. 2019 \\
\hline 3 & $\begin{array}{l}\text { SDN } 47 \text { Ampean, } \\
\text { Lombok Timur }\end{array}$ & $\begin{array}{l}\text { Ascaris Lumbricoides, Trichuris } \\
\text { Trichiura }\end{array}$ & $\begin{array}{l}\text { Triani et al. } \\
2020\end{array}$ \\
\hline 4 & $\begin{array}{l}\text { SDN Inpres No.1 Wora } \\
\text { Kecamatan Wera } \\
\text { Kabupaten Bima }\end{array}$ & $\begin{array}{l}\text { Ascaris Lumbricoides, } \\
\text { Trichiura, Hookworm }\end{array}$ & $\begin{array}{l}\text { Syahrir dan } \\
\text { Aswadi } 2016\end{array}$ \\
\hline 5 & $\begin{array}{l}\text { SDN } 4 \text { Sulangai, } \\
\text { Kabupaten Badung, Bali }\end{array}$ & Tidak ada data & $\begin{array}{l}\text { Krishnandita et } \\
\text { al. } 2019\end{array}$ \\
\hline 6 & $\begin{array}{l}\text { SDN I Manurung, } \\
\text { Kalimantan Selatan }\end{array}$ & $\begin{array}{l}\text { Trichuris } \\
\text { lumbricoides, }\end{array}$ & $\begin{array}{l}\text { Hairani dan } \\
\text { Juhairiyah } \\
2015\end{array}$ \\
\hline 7 & $\begin{array}{l}\text { SD di Kelurahan } \\
\text { Watusampu dan } \\
\text { kelurahan Lolu Utara, } \\
\text { Sulawesi Tengah }\end{array}$ & $\begin{array}{l}\text { Ascaris lumbricoides, T. trichiura, } \\
\text { Hookworm, E. vermicularis, } \\
\text { Trichostrongylus orientalis, dan A. } \\
\text { lumbricoides, T. trichura, Ascaris } \\
\text { lumbricoides, Hookworm }\end{array}$ & $\begin{array}{l}\text { Chadijah et al. } \\
2014\end{array}$ \\
\hline 8 & $\begin{array}{l}\text { Sekolah Dasar di } \\
\text { Puskesmas Rowosari } \\
\text { Kecamatan Tembalang } \\
\text { Semarang }\end{array}$ & Tidak ada data & Isma et al 2018 \\
\hline
\end{tabular}




\section{PEMBAHASAN}

Hasil penelitian melalui literatur review menunjukkan tingkat pravelensi Cacingan di beberapa daerah di Indonesia dapat berbeda-beda (Tabel 1, 2). Secara keseluruhan, dalam penelitian literatur review ini diperoleh 859 sampel dan terdapat 255 yang positif kecacingan dengan tingkat praveleansi total sebesar 29,7\%. Banyak faktor yang memengaruhi keberhasilan 0\% tingkat praveleansi kecacingan. Salah satunya adalah strategi pengendalian oleh pemerintah setempat untuk memberantas penyakit menular ini. Tingkat pengetahuan dari siswa dan orang tua pada perilaku hidup bersih juga menjadi tantangan tersendiri terhadap pemberantasan kecacingan. Hal inipun membutuhkan bantuan dan dukungan ketersediaan anggaran dana, fasilitas, dan sumber daya manusia yang kompeten dari regulasi pemerintah setempat untuk mendorong keberhasilan pencegahan kecacingan (Juhairiyah dan Annida 2014).

Analisis pada penelitian Mahmudah (2017) dan Isma et al. (2018) telah menunjukkan pengaruh kelayakan sanitasi lingkungan dan pengetahuan masyarakat dalam menurunkan penyakit kecacingan, berupa ketersediaan air bersih, jamban, sarana pembuangan limbah, dan pembuangan tempat sampah. Metode edukasi program kecacingan di sekolah secara umum dilakukan dengan penyampaian materi pada siswa, pemberian obat cacing, dan wawancara terhadap siswa/orang tua untuk mendukung kewaspadaan terhadap pravelensi kecacacingan.

Tingkat praveleansi kecacingan tinggi ditemukan pada Siawa di SDN 2 Malaka, Lombok Utara (55.5\%), SDN Inpres No.1 Wora Kecamatan Wera Kabupaten Bima (59,3\%), dan SDN I
Manurung, Kalimantan Selatan (68,4\%). Jenis cacing yang menginfeksi paling beragam ada pada Siswa SDN I Manurung, Kalimantan Selatan berupa T. trichiura, A. lumbricoides, Enterobius vermicularis, Hymenolepis sp., Hookworm, dan Infeksi campuran antara $T$. trichiura dan A. lumbricoides. Infeksi ganda menandakan buruknya kebersihan dan sanitasi pada lingkungan siswa.

Kasus kejadian kecacingan di SDN I Manurung dengan ragam cacing yang menginfeksi pada sampel tinja diduga karena kebiasaan cuci tangan sebelum makan dan setelah buang air besar, kebersihan kuku, perilaku jajan di sembarang tempat yang kebersihannya tidak dapat dikontrol (Hairani dan Juhairiyah 2015). Kasus penderita infeksi parasit usus di kampung pasar Keputran Utara Surabaya oleh Rosyidah dan Prasetyo 2018 menunjukkan infeksi Enterobiasis $28 \%$, Ascariasis 4\% dan Hymenolepiasis diminuta 4\%. Hasil tersebut selaras sanitasi lingkungan yang tidak baik, yaitu padat penduduk, sumber air bersih terbatas, dan kebiasaan buang air besar di sungai yang berisiko untuk penularan penyakit cacingan.

\section{SIMPULAN}

Hasil analisis berdasarkan literature review pada studi ini menunjukkan tingkat kesadaran masyarakat akan perilaku hidup bersih sangat penting untuk mencegah infeksi dan penularan kecacingan. Kebersihan tangan patut dijaga karena jalan utama perantara cacing dan telur cacing masuk ke tubuh manusia. Ketersediaan sanitasi lingkungan yang bersih dan terjaga di setiap rumah, sekolah, tempat kerja, tempat ibadah dan lainnya sangat mendukung kesuksesan pencegahan penyakit menular. Peran pihak 
pemerintah dan masyarakat setempat sebagai penggerak utama dan pendukung guna meningkatkan kesadaran dan kewaspadaan terhadap infeksi kecacingan.

\section{DAFTAR PUSTAKA}

Chadijah S, Sumolang PPF, Veridiana NN. 2014. Hubungan pengetahuan, perilaku, dan sanitasi lingkungan dengan angka kecacingan pada anak sekolah dasar di Kota Palu. Media Litbangkes. 24 (1): 50-56.

Hairani B, Juhairiyah. 2015. Infeksi cacing usus pada anak sekolah SDN I Manurung Kecamatan Kusan Hilir Kabupaten Tanah Bumbu Kalimantan Selatan tahun 2014. SPIRAKEL. 7(1): 38-44.

Isma SL, Sudaryanto, Helleyantoro R. 2018. Evaluasi program pemberantasan kecacingan pada siswa sekolah dasar di Puskesmas Rowosari Kecamatan Tembalang Semarang. Jurnal Kedokteran Diponegoro. 7(2): 551-561.

Juhairiyah, Annida. 2014. Kebijakan pengendalian kecacingan dan pengetahuan masyarakat terhadap kecacingan di Kabupaten Banjar Propinsi Kalimantan Selatan. Buletin Penelitian Sistem Kesehatan. 17(2): 185-192.

Kementerian Kesehatan. 2017. Peraturan Menteri Kesehatan Republik Indonesia Nomor 15 Tahun $2017 \quad$ Tentang Penanggulangan Cacingan.

Krishnandita M, Swastika IK, Sudarmaja IM. 2019. Prevalensi dan tingkat pengetahuan mengenai infeksi Soil Transmitted Helminth pada siswa SDN 4 Sulangai, Kabupaten Badung,
Bali. Jurnal Medika Udayana, 8(6): 1-10.

Mahmudah U. 2017. Hubungan sanitasi lingkungan rumah terhadap kejadian infeksi kecacingan pada anak sekolah dasar. Jurnal Kesehatan. 10(1): 32-39.

Rosyidah HN, Prasetyo H. 2018. Prevalence of intestinal helminthiasis in children at North Keputran Surabaya at 2017. Journal of Vocational Health Studies. 1: 117-120.

Sari PS, Triani E, Suryani D, Lestari RV. 2019. Pemeriksaan status gizi dan kecacingan di Wilayah SDN 2 Malaka Lombok Utara. Jurnal Pengabdian Magister Pendidikan IPA. (2)2: 153-157.

Syahrir, Aswadi. 2016. Faktor yang berhubungan dengan kejadian kecacingan pada siswa SDN Inpres No. 1 Wora Kecamatan Wera Kabupaten Bima. Higiene. 2(1): 42-48.

Triani E, Ajmala IE, Primayanti 1, Kusuma DR, Suwitasari P. 2020. Budaya mulut dan tangan sehat pada anak usia sekolah dasar di Desa Mamben Daya Kecamatan Wanasaba Kecamatan Lombok Timur. Jurnal PEPADU. 1(3): 345-348.

Winita R, Mulyati, Astuty H. 2012. Upaya pemberantasan kecacingan di sekolah dasar. Makara Kesehatan. 16(2): 65-71. 
Jurnal Penelitian Perawat Profesional, Volume 3 No 2 Hal 283 - 290, Mei 2021 Global Health Science Group 